\title{
Teaching World Mindedness in Social Studies \\ Classrooms in Primary Schools in Botswana: Reality or Illusion?
}

\author{
Mavis B. Mhlauli (Corresponding author) \\ University of Botswana, Department of Primary Education \\ Private Bag 00702, Gaborone, Botswana
}

Tel: 267-355-5090. Fax: 267-318-5096. E-mail: mhlaulim@mopipi.ub.bw

Received: September 3, 2013 Accepted: October 8, 2013 Published: November 29, 2013

doi:10.5296/ire.v2i1.4638

URL: http://dx.doi.org/10.5296/ire.v2i1.4638

\begin{abstract}
The need to teach global perspectives in schools has heightened with the proliferation of information sharing technologies and the growing interconnectedness of world systems, hence, the suggestion that if social studies is to do better in the preparation of global citizens for the future it has to pay attention to global perspectives. The purpose of this study was to interrogate the social studies teachers' views and experiences in teaching about the world in upper classes in primary schools in Botswana. For its framework, this study uses Hanvey' (1976) five dimensions of global education popularly known as "An attainable global perspective". This study was anchored within the naturalistic inquiry paradigm and used qualitative methods to collect data. Data were analyzed inductively through grounded theory techniques. The findings of this study indicated that social studies teachers teach about the world from a "Motswana" worldview. The conclusion drawn from these findings is that these teachers believe that teaching about Botswana is more of a priority than teaching about the world and their discussion on world issues is based on how those issues affect them as a country and a people. Therefore, the development of world mindedness in social studies classrooms remains an illusion rather than a reality. The study recommends that teacher education both pre-service and in-service revisit their curriculum in an effort to incorporate mega trends in social studies and global education and its pedagogies.
\end{abstract}

Keywords: Global education, world mindedness, global perspectives, instructional methods, social studies, primary education, global citizenship, Botswana 


\section{Introduction}

In order to prepare their students to be citizens of a global as well as a national society, prospective teachers need to themselves become comfortable as citizens of the world. They need to gain knowledge about the rest of the world and, through interaction with others, be able to take off their own country's glasses and look at the world from multiple perspectives (Wilson, 1993, p. 21).

The above quote, in particular, sets the tone for this paper as posits the challenge of preparing young children to be world minded and look at the world from multiple perspectives. Merryfield (1991) augments this assertion by confirming that there seems to be some consensus on what teachers need to know in order to teach with a global perspective. This involves knowledge and understanding of cultural universals and diversity, an appreciation of multiple perspectives, understanding of global interconnectedness, global issues and global systems.

Numerous calls have been made worldwide over the reexamination of educational programs and the incorporation of a global perspective in teaching to enable students to understand and benefit from the increasing interdependence of the world's cultures, economies, and political relationships (Merryfield, 1991; Tucker \& Cistone, 1991). The need to incorporate a global perspective in the United States has been reiterated by a number of organizations such as; The National Council for Accreditation of Teacher Education (NCATE) which stated in its accreditation standards that teacher education programs must include a global perspective, American Association of Colleges for Teacher Education, the American Association of State Colleges and Universities and the National Governors' Association (Merrfield,1991; Tucker \& Cistone,1991; Bruce, Podemski \& Anderson,1991). Merryfield (1991) further argues that despite all these recommendations at state and national levels the movement to achieve global perspectives in education is still lagging behind due to teachers' lack of knowledge of the world.

However, very little is known or said about teaching young children world mindedness in primary social studies and teacher education curricula in Botswana (Mhlauli, 2010). Botswana like many countries of the world is not immune to the effects of globalization and global dynamics. The need to teach global perspectives in primary schools in Botswana has also heightened due to: the proliferation of information sharing technologies; growing interconnectedness of world systems; emergence of transnational communities imagined or real; continued growth in the Diasporas and issues of cultural diversity and pluralism (Mhlauli, 2011). Hence, the need to insure that social studies teachers in primary schools in Botswana are conversant with teaching children world mindedness and insuring that they are taken onboard with regards to the development of mega trends in the social studies curriculum.

\subsection{Understanding World Mindedness}

World mindedness has been used in some quarters as a synonym of global education and or global perspectives. In simple terms world mindedness refers to teaching about the world. World mindedness is defined as knowledge, skills, and attitudes needed to live effectively in a 
world possessing limited natural resources and characterized by ethnic diversity, cultural pluralism, and increasing interdependence (Merryfield, 2012). It involves learning about problems and issues which cut across national boundaries and about the interconnectedness of systems may they be cultural, ecological, economic, political and technological (Merryfield \& Wilson, 2005). Global education involves "learning to understand and appreciate our neighbors with different cultural backgrounds from ours; to see the world through the eyes of others; and to realize that other people of the world need and want much the same things" (Holden \& Hicks, 2007, p. 14). Holden \& Hicks (2007) move further to include introspection, multiple perspectives and the use of technology as key elements of global education. The use of technology is pivotal to world mindedness as we live in a globalized and technologically driven world characterized by the interconnectedness of world systems. The heart of global education lies in enabling young people to participate in shaping a better, shared future for the world. Global education emphasises the unity and interdependence of human society, developing a sense of self and appreciation of cultural diversity, affirmation of social justice and human rights, as well as building peace and actions for a sustainable future in different times and places. Global education promotes positive values and assists students to take responsibility for their actions and to see themselves as global citizens who can contribute to a more peaceful, just and sustainable world (Global Education, n.d.). There is abundant literature that points to the relevance of infusing global perspectives into social studies teaching and learning in order to equip students with a better understanding of the increasing interdependence of world cultures, economies and political relationships (Merryfield, 1991; Tucker \& Cistone, 1991; Bruce, Podemski, \& Anderson, 1991).

In spite of the emphasis put on the need to teach with a global perspective, there have been criticisms from different quarters that global education is one of the most ambiguous innovations in education and that it is open to many interpretations which may lead to confusion, misconceptions and frustration hence the need for its meaning to be understood by all (Merryfield, 1993; Bruce, Podemski, \& Anderson, 1991; Tucker \& Cistone, 1991). As such, teachers need to thoughtfully and systematically work out a schema of what global education or world mindedness means to them as a concept and in their daily classroom practices (Merryfield, 1993). This would help them construct their own meaning and understanding of global education and its application in their instructional activities. Global education has also been labeled as controversial as it has been plagued by attacks from political and religious conservatives who are opposed to it (Bruce, Podemski, \& Anderson, 1991). The controversial nature of global education necessitates action from teacher educators to assist teachers to understand these controversies and devise ways to deal with them at different levels (Merryfield, 1993). It is imperative that teacher educators be proactive in helping teachers unpack and understand global perspectives as well as polishing their student teachers world view.

\subsection{Purpose of Study}

The major purpose of this study was to interrogate the social studies teachers' views and experiences in teaching about the world in upper classes in primary schools in Botswana. 


\subsection{Research Questions}

The study sought to address the following research questions (RQs):

(1) What issues do teachers teach about in social studies classes?

(2) How do teachers teach about cultures of the world?

(3) What are the teachers understandings of teaching about global connections

(4) What recommendations can be drawn from the findings of the study?

\subsection{Conceptual Framework}

This study uses Hanvey (1979) conceptual framework of "An Attainable Global Perspective" which comprises of five dimensions mainly: perspective consciousness, "state of the planet" awareness, cross-cultural awareness, knowledge of global dynamics, and awareness of human choices. Firstly, perspective consciousness implies the recognition of the existence of the malleability and diversity of perspectives. In any democratic society, it is vital that students are equipped with skills that develop multiple perspectives in order for them to understand the world better. Secondly, state of the planet awareness is about knowledge that the world extends beyond one's community and nation, what Myers (2006) would refer to as the world systems approach. Cross-cultural awareness refers to "Awareness of the diversity of ideas and practices to be found in human societies around the world, of how such ideas and practices compare, and including some limited recognition of how the ideas and ways of one's own society might be viewed from other vantage points" (Hanvey, 1976, p. 10). Cross cultural awareness is pivotal in that it creates in students' tolerance and open-mindedness which are essential tools in a diverse and multicultural society that our students live in.

Knowledge of global dynamics requires understanding of how the world works and this includes change in social systems, advances in technological innovation and global planning. The interdependence of countries within the global village necessitates that students be knowledgeable about world systems. Awareness of human choices refers to some awareness of the problems of choice confronting individuals, nations and the human species as consciousness (Hanvey, 1976). This framework articulates practical ways in which global perspectives could be attained in a school environment. The use of Hanvey's framework for this study is imperative as it is aligned to how the discourse on global education is conceptualized and practiced within social studies classrooms world-wide. Furthermore, it helps unpack the subtleties embedded in the teachers' understandings and practices of global education in social studies classrooms in primary schools in Botswana.

\section{Literature Review}

Research carried out on infusing global perspectives in educational programs is abundant, however, most of the literature is conceptual and focuses more on crossing cultures and cultural immersion (Merryfield, 1993; Bruce, Podemski \& Anderson, 1991; Tucker \& Cistone, 1991). Merryfield (1991) conducted a study on the preparation of secondary social studies teachers to teach with a global perspective. The study identified only thirty programs throughout the 
United States that prepared teachers for a global perspective. In another study, Merryfield (2000) findings revealed some deficiencies in teacher education programs that teachers are not being prepared to teach for diversity, equity and interconnectedness, noting that the question of why teacher education is not preparing teachers well will continue to dominate the discussions in teacher education.

Myers (2006) opines that although there is some consistency in the basic principles that underpin teaching about the world, there are diverse ideological approaches to teaching about the world in terms of goals and curriculum themes. Three approaches to teaching about the world identified are: international business training, international studies, and world system approach (Myers, 2006). Of the three approaches espoused in Myers (2006), the most predominantly found within the social studies literature is the world system approach (Hanvey, 1976; Merryfield \& Wilson, 2005; Holden \& Hicks, 2007; Merryfield, 2012). Based on the world systems approach, various instructional methods have been used to infuse global perspectives in different programs such as social studies and teacher education in general. These instructional methods can be categorized into two; those that deal with crossing cultures and immersion and those that are content related. This paper examines at least four instructional methods that concentrate on cross- cultural experiences and two that deal with content. The instructional methods discussed in this literature review are among the many methods that have been suggested and the list is not exhaustive.

\subsection{Cross-Cultural Experiences}

There are many ways to infuse global education through cross-cultural experiences and this paper examines personal experience, international experience, on-campus cross-cultural experiences and conversation partner programs.

\subsubsection{Personal Experiences}

The power of personal experiences in helping teacher educators to infuse global perspectives into their programs cannot be underestimated. Students can best appreciate global education through personal experiences by working in schools that serve different cultural or national communities, relating to people from diverse cultures and nationalities and integrating with contrasting communities (Bruce, Podemski \& Anderson, 1991). The use of guest speakers in personal experiences has been seen to be fruitful in making learning meaningful and relevant in that it brings pre-service teachers into contact with people of different backgrounds and cultures that they may not otherwise have a chance to encounter (Haakenson, 1999). Personal experiences are said to promote in-depth learning that cannot be replicated in classrooms. Merryfield (1997) augments the power of guest speakers as an instructional method for infusing global education in social studies but sees them as resources for teaching multiple perspectives or developing perspective consciousness. Perspective consciousness is important in that it helps students study other people's viewpoints.

\subsubsection{International Experience}

Another popular instructional method for infusing global perspectives is cross-cultural experiences. Cross-cultural experiences usually take the form of international experience or 
study abroad programs where students visit, teach and interact with people from various cultures. Therefore, creating more opportunities for international or study abroad for preservice teachers can be an ideal way to help them gain a global perspective (Haakenson, 1999). International teaching experiences are said to be powerful in changing beginning teachers' thinking about themselves, curriculum design, and teaching strategies; enhance skills and abilities of effective teachers; force examination of personal beliefs, habits and values; increase their motivation to teach about global issues and encourage commitment to open-mindedness (Willard-Holt, 2001; Holden \& Hicks, 2007). The impact of International experience is well captured in the illustration of the story of Diane, a University of Kentucky graduate who did her teaching in a small village school in England. She learned some British history, gained a British perspective from the host family as well as young students who taught her to use the words like "rubber" and "boot" in new ways. She returned to Kentucky a more self- confident woman and has been to England to visit friends (Wilson, 1993).

\subsubsection{On-Campus Cross-Cultural Experiences}

The third strategy focuses on On-Campus cross-cultural experience. This approach is seen as an alternative to international experience or study abroad since not all students can afford to participate in such experiences. On-campus cross cultural experiences encourages teacher education programs to seek out for people who have had cross-cultural experience or international experience as well as international students and use them as resources (Wilson, 1993). Wilson (1993) in her study found that cross-cultural interactions between American and international students "is significantly related to acceptance of cultural pluralism, support of internationalism, a cosmopolitan world outlook, and world-mindedness- all concepts that can be subsumed under perceptual global perspective" (p. 23). An alternative way of on-campus cross-cultural experience is what Merryfield (1997) would term "connections to students' lives". It is similar to Wilson's (1993) idea in that teachers use their knowledge of their students' backgrounds, experiences, abilities, and interests to motivate and teach them about local-global connections and their place in the world.

\subsubsection{Conversation Partner Programs}

The conversation partner program is a program at the University of Kentucky that pairs English-as-a second-language international students with elementary and middle social studies majors in order to create cross cultural experiences (Wilson, 1993; Haakenson, 1999). This program provides pre-service teachers with an on-campus cross-cultural experience that heightens their intercultural competence. The program has been viewed as successful in helping students gain substantive knowledge and perceptual understanding, personal development, and interpersonal relationships (Wilson, 1993).

\subsection{Content Related Instructional Methods}

Instructional methods that concentrate on content have been identified and this paper focuses on only three of them. The three methods discussed here are some of the methods used to infuse global perspectives. 


\subsubsection{Modifying Existing Courses}

One of the instructional methods that focus on content is that of modifying the existing curricula to incorporate global perspectives. Some of the subjects that have been identified as feasible areas for global education are general studies, foundations of education and curriculum studies (Bruce, Podemski \& Anderson, 1991). These authors further assert that such subject areas have been chosen because they are seen to offer many opportunities to introduce students to global knowledge. Tucker \& Cistone (1991) further argue that academic disciplines have the potential to incorporate global knowledge and propose the use of history as its content is linked to global perspectives. Their argument is that the way history is written, taught and learned links the present with the future and past and therefore, reflecting all macro issues of global education through global history.

\subsubsection{Development of New Global Courses}

Another instructional method that can be used to infuse global perspectives is through the development new courses. Such courses are often organized around themes and issues in order to bring several disciplines together for a more holistic examination of the world (Merryfield, 1997). This approach is further exemplified in the narrative of how Steve Shapiro teamed up with four other teachers at Reynoldsburg High School in Ohio, to integrate social studies, math, science, art, and language into global connections. This project provided ninety tenth-grade students with interdisciplinary and in-depth study of global issues related to the environment, and themes such as culture, conflict and historical connections (Merryfield, 1997).

\subsubsection{Infusion Experiments}

The fifth strategy that can help pre-service teachers understand and infuse global education is through experimenting with actual global perspectives. Infusion experiments allow teachers to experiment with global perspectives in their own teaching through lesson plans, teaching and assessment and later reflect on their own teaching (Merryfield, 1993). The idea of infusion experiments is in line with the methods used in a study conducted by Willard-Holt (2001) where she examined the impact of cross-cultural teaching experience. The study involved 27 pre-service teachers most of whom were White at Penn State-Capital College. These students were given a questionnaire prior to their trip to Pachuca, Mexico. Upon return from the trip they were given their pre-questionnaires and asked to amend any of their previous responses based on what they learned during their stay in Mexico.

Four months later the pre-service teachers were asked in the form of a questionnaire to assess the impact of the trip on their student teaching. The results indicated that $80 \%$ of pre-service teachers integrated content from their trip, $60 \%$ taught and learned more about countries of the world and $60 \%$ reported change towards teaching with sensitivity and empathy (Willard-Holt, 2001). This project is in tandem with Merryfield (1993) idea of infusion experiments in that pre-service teachers were to use their international experience in their lesson planning, content and real teaching, and reflect on its impact on their teaching. This strategy is important in that it combines both content and the development of skills among student teachers. 


\section{Research Methodology}

The study was qualitative in its approach and employed the naturalistic inquiry paradigm (Lincoln \& Guba, 1985). Naturalistic inquiry is said to demand a natural setting. This is so because "phenomena of study, whatever they may be- physical, chemical, biological, social, psychological- take their meaning as much from their contexts as they do from themselves" (Lincoln \& Guba, 1985, p. 189). The study focused on eleven (11) exemplary social studies teachers in six (6) primary schools in one of the major villages in the central district in Botswana for a period of three (3) months (January -April, 2010). Of the eleven teachers four were males and seven were females. The teachers' age ranged between 30 and 55 years; where four teachers were between 30 and 35 years, three were between 36 and 45 years, two were between 46 and 50 and two were between $51-55$ years. In this study the village is referred to as Maretlweng (pseudonym). Purposeful sampling through snowball or chain sampling was used to select the participants. The major aim of purposive sampling also referred to as theoretical sampling is to "select information-rich cases for study in depth" (Patton, 1990, p. 169). The naturalistic inquirer prefers purposive sampling because it allows for the increase of the scope and range of data and the likelihood that a full array of multiple realities will be uncovered; it also maximizes the researcher's ability to devise grounded theory that "takes account of local conditions, local mutual shaping's, and local values" (Lincoln \& Guba, 1985, p. 40).

The study used qualitative methods for data collection which included individual interviews, focus groups, participant observations, and document analysis for triangulation purposes. Data were analyzed inductively using grounded theory techniques through the constant comparative technique (LeCompte \& Preissle, 1993). Data were collected, transcribed, coded and categorized in order to inform the next interviews and observations. In explaining constant comparative analysis it is stated that it "combines inductive category coding with a simultaneous comparison of all social incidents observed and coded" (LeCompte \& Preissle, 1993, p. 256). Data analysis took place at the same time with data collection and I constantly used the questions raised during transcription to shape the questions for the next interviews. This process allowed me to mine the data thoroughly in order to exhaust all possible gaps. Pseudonyms were used to protect the participants' anonymity.

\subsection{Limitations of the Study}

The study was limited to only eleven selected social studies teachers' and the findings from the study cannot be generalized to all social studies teachers in primary schools in Botswana. The use of multi-site posed some challenges as I could not be in all the schools at the same time. This inability to be in all schools at the same time affected my data collection at times. For instance, during the commonwealth day celebrations I was unable to observe what was happening in all the schools due to time constraints and the distance between the schools.

The research was prone to the researcher's cultural biases as I am a Motswana and teacher educator within Botswana. The school time-table also provided some challenges as it was not flexible enough due to the fact that it was centralized and as such social studies was taught at the same time in all the schools that participated. This posed some limitations as it was often difficult for me to hop from one school to the other. The introduction of specialization also 
posed problems for teachers as it was confusing for them and they were unable to afford any flexibility with the time-table or topics taught which often affected our schedules for interviews and observations.

\section{Findings and Discussions}

The major findings indicate that teachers teach about the world from a "Motswana" worldview. To them teaching about Botswana is more of a priority than teaching about the world and their discussion on world issues is based on how those issues affect them as a country and a people. Historically, there are many reasons that may explain the teachers' worldview that are related to the colonial legacy. Firstly, the colonial education system was oriented towards instilling western values and beliefs and upon independence Botswana like many African countries transformed its education into an African-centered education such that it reflected the views, needs and aspirations of the Batswana (People of Botswana). Secondly, this Afro-centered education necessitated that aspects of the curriculum such as the objectives, content, methods and resources be redirected to reflect the lives of the indigenous people it was supposed to serve (Merryfield \& Tlou, 1995).

Thirdly, the Africanization of the school curriculum was seen as a means to nation building and the development of citizens. As a result of all this, the social studies curriculum was revised to reflect the culture, language, literature and traditions of Batswana and adopted an approach to teaching where students had to learn about their immediate environment before learning about the distant environments (Mautle, 2000; Merryfield \& Tlou, 1995). This premise has characterized curriculum development at primary education level in Botswana ever since. It is therefore, not surprising to find that teachers perceive teaching about Botswana as more of a priority than teaching about the world. The teachers real names were not used for this study instead pseudonyms (Nkwe, Kabo, Kgabo, Kubu, Morubisi, Batho, Lorato, Neo, Mpho, Thato and Tau). The findings of this study will be discussed according to the themes that were generated from the research questions (RQ's) such as; teaching about world issues, teaching about world cultures and understanding global connections.

\subsection{RQ1: Teaching about World Issues}

Teachers believed that they teach about issues that are taking place around the world. The issues that they said they discuss in their teaching revolved around socio-political issues such as poverty, conflicts and wars, and tribalism. They also mentioned discussing environmental and economic issues. The issues raised here are in line with Hanvey (1976) perspective of awareness of human choices which Myers (2006) would classify under the world systems approach which focuses on the interdependent nature of states around the world. They felt that these issues were important in that they are happening around them and may as well happen to them. The sentiments of teaching about world issues that are a concern to them are a clear indication of the teachers' worldview. The worldview that these teachers hold translates into their practices in the classroom as evidenced by what they said below. 


\subsubsection{Socio-Political Issues (Poverty, Conflicts/Wars, Tribalism)}

Teachers talked about the socio-political issues that were a concern to them such as poverty, conflicts and wars, religion and tribalism. There was an intersection of issues such that it was difficult for teachers to discuss each one in isolation as they are typically interwoven. These issues were important to them because they affected people in the African continent and their immediate neighbors. Talking about the relevance of teaching about poverty $\mathrm{Mr} \mathrm{Tau}$ had this to say:

I discuss issues of Poverty so that students are aware of what is happening in the country and other African countries such as Ethiopia, Somalia, Zimbabwe, Malawi, Rwanda, Uganda, Kenya and other countries that I have not mentioned. I make students understand that what is happening in these countries may happen to them one day. The importance of teaching about these issues is to develop citizens who can understand other people's problems, be compassionate, caring and supportive.

Ms Kubu also spoke about discussing issues on poverty and explained that:

We discuss issues about starvation or Poverty. Most African countries are experiencing some political unrest and as such their people are caught in poverty due to wars and conflicts.

Teachers also talked about conflicts and wars and their implications as well as conflict resolution. They reiterated on the consequences of conflicts such as refugees, competition for social amenities and the job market. Ms Kabo had this to say about conflicts and wars:

Conflicts in other countries, like the Zimbabwean issue, and it is affecting us because those people are coming here and some of them seek medication and end up getting medication which could be used by Batswana. They get job opportunities. If today Botswana finds itself fighting with Zimbabwe or Namibia what it means is that some Batswana might find themselves in Zambia, Malawi or South Africa as refugees. We have refugees; we have people moving from those countries to other countries for security reasons.

Ms Thato talked about the need to teach about conflict resolution and said that:

The other one I talked about earlier on that I discuss with my students is conflict resolution, that there are different conflicts around the world, people fighting over the borders, where they share resources. They know that they have to come together discuss issues peacefully and come up with solutions to the problems rather than fight. The countries should listen to one another.

Ms Batho also weighed in on teaching about conflict resolution and associated it with issues about human rights and said:

They should think about ways that countries affected by wars can apply to resolve their problems...Ifyou teach them about human rights they should know that the rights 
that they are having in that country is the right that other people in outside their country should have.

Some of the socio-political issues that teachers said they taught their students about were on discrimination on the basis of ethnicity, tribalism and race. Ms Lorato who belongs to one of the so called "minor" ethnic groups was very critical about teaching about issues of tribalism and mentioned that:

I also teach them about tribalism because this is a concern since in other countries people have gone to war because of tribalism where some tribes are regarded as minor while others are seen as major tribes. This may cause emotions as our grandparents have fought for this country and we are not recognized. Knowing about these things will help us avoid problems like riots and discrimination which have caused civil wars in other countries. Citizens should know what is taking place in the world...I think there is an issue of tribalism that I think even today tribalism is still there I think to the extent that some people do not feel free to identify themselves with their ethnicity.

Mr Tau spoke elaborately on ethnicity arguing that students need to be taught about what is happening around the world as these conflicts can provide teachable moments for Botswana. Reacting to teaching about issues of ethnicity echoed that:

Ethnicity-One area where people are discriminated in is due to their ethnicity. For example many countries have gone to war because of discrimination based on ethnicity. Even in Botswana here the issue of major and minor tribes nearly divided the nation if it was not attended immediately. The world has witnessed genocides in countries like Rwanda/Burundi between the Hutu and the Tutsi. Such things should be avoided at all costs. As we speak there are riots in Nigeria based on either Ethnicity or religion between the Christians and Muslims. Let's look at what is happening in Iraq, Iran, Palestine, Afghanistan and many other countries in the Middle East. There are serious lessons that we can learn from these countries that are marred with conflicts.

Ms Kabo spoke about discrimination on the basis of ethnicity and race and how these provide a breeding space for xenophobia citing the way Batswana treat Zimbabweans who are in the country due to economic problems in their country, she said that:

Yes I do teach about issues of difference such as discrimination on the basis of ethnicity; xenophobia that is; ill-treating of foreigners like where Batswana mistreat Zimbabweans while knowing what they are experiencing. We talk about racism because it violates other people's human rights and freedoms as we saw it dividing people in the former South Africa. We discourage our students from thinking that some people are better than others based on the colour of their skin. This is bad and can divide a nation.

The findings in this category do indicate that teachers teach about issues that they believe affect them either directly or indirectly such as poverty, conflict and discrimination. To them these issues are important as they might find themselves in the same situation. Their concerns are 
valid in view of the fact that Africa, where Botswana is situated is always portrayed as a continent in turmoil due to wars, conflicts and disease. There is never a situation where the continent is portrayed as peaceful or progressive economically as is the case with Botswana. There is need for these teachers to be able to recognize these stereotypes and misinformation and make their students aware of the realities of life.

\subsubsection{Environmental Issues and Natural Disasters}

Almost all of the teachers talked about teaching about environmental issues and natural disasters. They reiterated on how these environmental issues and natural disasters affected people socially, psychologically and economically. Their argument was that students need to learn about these issues because they have an effect on their lives even if they are taking place elsewhere and used global warming to illustrate global interconnectedness. Ms Mpho mentioned that:

We discuss about environmental issues because what is happening in other countries may also affect us for example, some areas have turned into deserts due to human activities. We talk about climatic issues such as global warming, the effects of factories and industries on the depletion of the ozone layer.

Teachers also spoke about natural disasters and their effects on people's lives and an excerpt below from $M r$ Nkwe's interview explicitly shows his opinion with regards to natural disasters that:

Global issues like natural disasters, like in Haiti, children must understand the problems that those people could be facing today as a result of what happened to them because that can also happen in our country. They must understand the social effects of those natural disasters or of that earthquake, that people will lose their relatives; some will lose their parents, siblings. You will find that as a child you will be adopted maybe live her life to the fullest knowing that her mother was found dead buried by buildings that just collapsed on top. Yes, we discuss about natural disasters, how they affect peoples' lives and how they can be reduced.

In their focus groups teachers spoke about water conservation, what they called "water economy" as Botswana is prone to drought and unreliable and insufficient rainfall. Their argument was based on how countries depend on one another and the commonalities that they share in terms of resources. One of the male participants had this to say:

Water economy; especially in Southern Africa where a lot of countries are dry and water is very scarce. As well as shortage of power where electricity is scarce like in Southern Africa E.g. Lesotho relies on South Africa in terms of water whereas Botswana relies on South Africa for power. There is need to maintain good relations with other countries to share and preserve the natural resources that are scarce such as water in Botswana. Students need to understand the importance of such resources and that is why I teach about them. 
It is interesting that teachers did not speak about the immediate environmental issues that Botswana is prone to such as pollution, desertification, drought and floods. This may be due to the fact that they see world issues in relation to how they affect them from outside.

\subsubsection{Economic Issues}

One of the economic issues that teachers talked about was the economic recession. They felt that students need to know about the economic crisis that some countries are going through. Ms Neo was very adamant that students have to learn about the world economic recession and said that:

We are living with recession today, we must know that this economic problem is not for us only it affects the whole world and we teach them precautions of what the government is doing to help stabilize this, what we have to do so that at the end we are not hard hit like other countries will be.

Mr Tau echoed his views on teaching about the economic recession by emphasizing wise use of resources citing examples from neighboring Zimbabwe that:

Economic recession, that is, if we have the resources we have to manage them and use them wisely, because if we happen to just use them wrongly, we might end up having a problem, like we often hear that in some countries they owe the World Bank, so we have to be careful. I teach about the economic crisis and use example of countries like Zimbabwe which used to be very rich and are now faced with starvation.

The findings from this category clearly show that teachers teach about Botswana from a "Motswana" worldview in that they spoke to issues that resonated with their livelihoods and as such were given a priority in their teaching.

\subsection{RQ2: Teaching about Other Cultures of the World}

The findings under this category indicate that teachers felt that in teaching about the world it was important to teach students about other cultures that were not in Botswana. The teachers' views and experiences are in tandem with Hanvey's (1976) notion of cross-cultural awareness. Cross-cultural awareness and understanding is the most popularly held approach to global education among social studies classrooms world-wide (Merryfield, 2012; Myers, 2006, Merryfield \& Wilson, 2005; Wilson, 1993). They attributed the need to learn about other cultures to globalization and trans-border migration. Their discussion focused on the reasons for learning about different cultures and how they help their students learn about other cultures.

\subsubsection{Learning about Different Cultures}

Almost all teachers talked about the need to discuss about different cultures. They provided a variety of reasons for learning about other cultures among them; developing understanding and appreciation of other people, tolerance, avoiding cultural shock and promoting peace and harmony. The overwhelming support of teaching about other cultures is not surprising in that Botswana is a multicultural society and yet some ethnic groups' cultures have gone unrecognized for many years under the pretext that it is a homogeneous society. Therefore, 
marginalized groups are beginning to realize the need to teach about their cultures and have sought recognition within the curriculum, which is why today the social studies curriculum no longer talks about the eight principal tribes only but incorporates the different ethnic groups that are found in the country. The issue of international migration has also affected how teachers teach about other cultures as they find students in their classrooms who are not Batswana by origin or are refugees as well as a result of the need to seek careers elsewhere.

Mr Tau eloquently justified the need to teach students about different cultures and said that:

Yes, it is important to learn about other cultures because life is a journey; you never know where you will end up. We need to learn about other cultures in order to tolerate one another and be united as the human race. Globalization has made the world smaller therefore we need to understand other cultures as we may find ourselves in such countries one day. Knowledge and understanding about other cultures helps in promoting good communication and such interaction becomes easy. There is also an acceptance of difference also become easier as people are aware of such differences. There is also understanding of other cultures making it possible for people to livepeacefully.

Mr Nkwe not only provided a justification for teaching about other cultures but addressed the notion of global mobility that:

When going to other countries, we will not be in a situation where we have cultural shock. This knowledge will make us fit well in other cultures; Accommodate other cultures also who are different. Knowledge about other cultures will help us avoid conflicts, misunderstandings and wars that are based on cultural ignorance and stereotypes. This knowledge of other cultures will help promote the culture of peace which is already prevailing in our country Botswana. Teaching about other cultures will lead to avoiding conflicts, promote peace, and curbing issues of xenophobia that we see happening in South Africa where foreigners are being brutally whipped and killed because it is believed that they are taking jobs that are meant for South Africans

The findings in this category indicate that teachers see the importance of teaching about different cultures but they are weary about external influences from other countries since they emphasize the need to maintain peace and relations in their country.

\subsubsection{Cross-Cultural Understanding}

Teachers also talked about the ways in which they infuse cross-cultural understandings in their teaching. They talked about using field trips, guest speakers and pen pals. Mr Tau who is a well experienced teacher and who has travelled to other countries outside the region such as the United Kingdom and United States mentioned that he requires his students to write pen pals to learn about other people and this is what he said:

Through composition of letters such as writing to a pen-friend to establish a relationship with their counterparts in other countries. For example, when I was teaching at Mafithakgosi primary school in Tlokweng (village) my class had 
pen-friends with students in Carmarthen; Wales in the United Kingdom. They wrote letters to one another and shared information about school activities, home, country, culture and many other issues.

Mr Nkwe who attempted his Masters' degree in the United States had this to say about what he does in his class:

In my social studies classes for instance, I have been encouraging students to write pen pals letters where students write to other students in other countries and talk about Botswana, I remember in 2001 when America was hit in the trade centers, when the Americans were now beginning to understand what was happening they encouraged some children to write to some children in Iraq to exchange ideas on what is happening. I was there in 2001. So Pen pals is one of them, the other thing is visiting, the curriculum allows us that we should be taking international trips so that our students can go and learn about cultures of other countries and see how other countries look like.

Ms Lorato who seemed to develop world-mindedness among her students uttered the sentiments below that:

I encourage pupils to learn other languages. For example there are Chinese, Indians and other people from different countries; they need to learn at least how to greet in those languages that are not based in Botswana. I usually give them group projects where they go and inquire about any culture of people who are not from Botswana and come back to present to the whole class. This will help them if they have to live in other countries outside Botswana.

In one of the focus group discussions, teachers mentioned the use of guest speakers and field trips. One of the male participants had this to say:

We do invite people like chiefs, head men to be our resource person to come and explain further about how things are done and how they were done in the past. Sometimes we take field trips during school holidays where we learn about other cultures and communities in the country.

A female participant in the focus groups said that:

Sometimes we take kids on a field trip so that they see places like in Botswana, they visited some places where there are paintings, road tracking's that were done by the Basarwa etc. Field trips are good the only problem is that they are expensive to undertake and most of the time parents do not have money to fund them.

The findings in this category show some disparities between teachers views on cross cultural teaching and understanding. Teachers who have been outside the country talked about their experiences and what they saw happening in other countries. However, teachers who have not travelled outside the country talked about guest speakers and field trips within the confines of the country hence indicating that to them teaching about other cultures meant teaching about cultures in Botswana. The findings on teaching about other cultures corroborate Myers (2006) 
findings that the teachers' bringing of guest speakers and celebrating culture days addressed the conundrum of dealing with their own ethnocentrism and awareness of cultural diversity rather than developing world mindedness among citizens. Even though some of the teachers talked about teaching about other cultures, they lamented that due to time constraints and the need to cover the syllabus for examinations, they were unable to do some of the activities mentioned. These findings are indicative of the realities of not preparing students to be global citizens.

\subsection{RQ3: Understanding Global Connections}

The findings in this category are in tandem with Hanvey (1979) perspective on knowledge of global systems in that teachers put more emphasis of global systems and governance. Teachers felt that students need to know and understand that the world is interconnected as countries are dependent on one another for survival. They felt that students need to know about the challenges that the world is faced with and should be equipped with the necessary skills to be able to confront such challenges. During their focus groups one male participant explained the interdependent nature of countries of the world and said:

Make the pupils understand that the world is a globe, we belong together, and we should make the pupils understand that we belong together but separated by oceans. Make them aware that what is done in our country might be done somewhere else; if it has negative impact it might affect all. For instance; the issue of global warming and gasses which affect the ozone layer, if one country is affected it might affect all. Issues of political stability, if one country is affected neighbours may be affected, for example, many refugees may go to neighbours' countries that would spend a lot of money on that and as such host countries would use a lot of resources that might have been used for other developments.

Teachers felt that the people of the world are connected socially, economically, and politically. This interconnectedness was discussed from a "Motswana" point of view in that they related what is taking place in their country to the world. The views held by the teachers to approach issues from a "Motswana" perspective dovetails with the expanding horizons phenomenon that requires that students be exposed to the immediate environment first before learning about environments that are far away from their realities. This approach to curriculum development and implementation has been the cornerstone of curriculum innovation and implementation in Botswana since independence.

\subsubsection{Socially: Communications and Technology}

Almost all of the teachers said that they taught their students about technology and how it has influenced their lives and how it has turned the world into a small global village. They talked about the impact of computers, internet, cell phones and text messaging in making communication easy and accessibility to information quicker. Speaking about the power of technology and how it has transformed communication and information sharing $\mathrm{Mr}$ Kgabo commented that: 
Communication has changed due to interaction and technology. Today we communicate using the internet and email and we can communicate with peoplein Europe while here due to technology.

Ms Lorato mentioned on how technology has connected them to other parts of the world and said:

As we discussed that is when they will learn more on technology that it is really improving their lives and interconnecting them with other countries like cell phones we used to. Nowadays we use telephones and cell phones, internet and text messages. So you see that we are connected you can communicate with your relatives abroad when you are still in Botswana.

The significance of technology as a source of information was also discussed and $\mathrm{Mr} N \mathrm{Nwe}$ remarked that:

I teach them about the use of technology, the internet, computers even the media. For them to know the information around the world they need to use the internet like if there are wars around the world they need to know all these things. Knowledge must be in line with what the outer world supports. What we do is affecting others as well for example; the issue of Haiti, media informed the nation and nation made a contribution towards that.

Even though teachers appreciated the role of social media in making the world smaller through interconnecting people from diverse worlds, it was not surprising that they talked about the availability of these communication modes and did not practice using either the computer or the internet. Teachers appeared to provide information of what is available out there to students but were limited by the unavailability of such resources in schools for students and teachers to use. What came out very clearly was that teachers were computer illiterate hence the need for the Ministry of Education \& Skills Development to embark on a rigorous plan to educate teachers on the use of technology in teaching.

\subsubsection{Economically: Trade}

Teachers also talked about how Botswana is connected to other parts of the world and what they teach their students. They alluded to the fact that they teach their students about maintaining global connections by focusing on trade relations based on imports and exports that Botswana shares with other countries of the world as shown in the syllabus. An analysis of the syllabus indicated that issues of trade are addressed from standard 5 -7 and a lot of emphasis is put on how Botswana relates with other countries economically in terms of exports and imports. In their focus groups teachers talked about the geographical position of Botswana and how it necessitates that Botswana maintain good relations with other countries, an excerpt from the discussion follows below:

Like we are saying, Botswana being a landlocked country, students have to know how do we import and export our commodities outside the country and inside the country. They have to know that, we connect with other countries that are our neighbors to 
get access to the ports, since we don't have them. We also do it by teaching those ways of investing like we are selling our diamonds in Europe which shows connections. That alone shows that we are connected to other people.

Another participant shared the same view and uttered this:

Things that we produce, we import and export, what they do not have there in their countries, we have them in our country. For example we export beef to European Union and we see them as our economic partners. It is because we rely on other countries. We get other things from other countries. We buy exchange and visit different countries. We also have raw materials and minerals which make us have good relations with other countries in the world.

Teachers expressed the need to help students understand global connections and this was done through discussing the importance of trade noting that the world is interconnected and no country can be able to live in isolation, that as countries we need each other in order to survive and continue to develop. It is interesting that teachers seemed to concentrate on creating awareness as opposed to engaging in activities that reflected global connections; this scenario raises questions on teacher preparation on global education in general. However, it was clear that they talked about trade issues because they are in the syllabus and they are compelled to teach about them.

\subsubsection{Politically: International Relations}

Teachers also said that they teach their students about global connections through discussing political issues on international relations. They argued that countries are connected through international, continental and regional organizations. Speaking about the interdependence among nations of the world $M r$ Nkwe said:

The issue of co-existence, countries or nations try to live in peace with each other because of bilateral relations and lateral relations. You find that there are groupings such as SADC, SACU etc. There is also the AU, and Africa must live with other continents especially in Europe and America because they need a lot of resources from Africa. There must be an understanding on how these could be done. We know that our diamonds were just about to be named "blood diamonds" and our government had to stand up and talk a lot about that to associate with the financial community about the idea and because of co-existence and the original bodies.

They also saw global connections being actualized through organizations that had certain things in common and in their focus groups this is what Mr Tau said that:

I perceive that through identity, We Africans identify with the continent of Africa e.g. if we say "we Africans", we are trying to tell people that we have something in common. We also identify with regional groupings such as SADC, AU since these emphasize a sense of belonging to say "I belong to these groups of people and we share the same challenges" This helps us in strengthening relationships as well as benchmarking. 
Ms Kubu puts emphasis on global connections through organizations made up of countries that share the same history and had this to say:

Through the commonwealth, countries which were former colonies of Britain now exist in a political way through the Commonwealth, where they exchange ideas. Organizations like the commonwealth activities bring us together and show us that we have certain things in common for example we were all once colonies of Britain. That helps see ourselves as having things in common. They are made aware that Botswana is one of the commonwealth countries and therefore, they see that we are not doing things in isolation.

Teachers also discussed the importance of celebrations as an indication of global connections and $M r N k w e$ had this to say:

We have days of celebrations for example, World AIDS day to help them take AIDS/HIV seriously as other parts of the world are serious about it. We have Commonwealth Day, International Day of the child and the Day of African Child. We also teach them and share with them on international issues.

Though teachers saw the need to teach about global issues, their approach to such issues was largely influenced by their socio-political experiences and the history of their country, a situation that needs to change if teachers indeed have to prepare their students to be able to live in a relatively competitive global world and be able to survive. Moreover, teachers did not see teaching about global systems as a necessity except that it was in the syllabus and needed to be taught. Their belief was that the government's membership and participation in international organizations and global governance suffices in insuring that they are global players. This view is detrimental to the development of citizens in a democracy as it prepares students to be recipients as opposed to players in the global arena.

\section{RQ4: Conclusions and Recommendations}

From the findings of this study it is evident that the social studies teachers teach about the world from a "Motswana" worldview, implying that what is important to them is that which affects them. It has also become more apparent that preparing to teach with a global perspective in social studies classrooms in Botswana primary schools is both challenging and multifaceted. It involves developing substantive knowledge, presenting teaching strategies and instilling a commitment in teachers to teach within a global framework (Wilson, 1993; Haakenson, 1999). From these findings, it is clear that out of Hanvey's (1979) five perspectives, only two, that is, cross-cultural awareness and knowledge of global dynamics are predominantly talked about in social studies classes in upper primary schools in Botswana. The other three which are perspective consciousness, awareness of human choices and the state of the planet awareness perspectives were not mentioned by the teachers. These findings are troubling in that Botswana is a democracy, and failure to teach students to probe, reflect and empathize; which are key aspects of perspective consciousness is detrimental to the development of knowledgeable and informed citizens as espoused in Vision 2016. It was surprising that teachers did not mention issues relating to the state of the planet awareness perspective yet they had topics in the 
syllabus that focused on physical and social geography. In conclusion, it is fair to assert that social studies teachers in primary schools in Botswana are not well prepared to teach global perspectives hence making the development of world mindedness among students an illusion rather than a reality.

One way to strengthen teaching with a global perspective is to "walk the walk and talk the talk more" which according to Haakenson (1999) means that teacher educators need to make learning relevant, integrate technology, use performance-based assessments, and create opportunities for interdisciplinary instruction. Global electronic mail programs such as the London-based Campus 2000, which link institutions of higher education with primary and secondary schools and selected other countries give students the opportunity to share information and communicate with fellow students elsewhere (Bruce, Podemski, \& Anderson, 1991). Through satellite, students can observe educational experiences in other countries and by doing so making learning more relevant and real. The use of technology for strengthening global perspectives is augmented by the findings of a survey by Merryfield (1991) that suggested that secondary social studies teachers were not being prepared to teach about the environment and technology and the argument being that it is difficult to understand the world without knowledge of environmental issues and the state of the planet. Pre-service teachers need to be prepared to teach from a global perspective if we need to produce citizens for a global society.

Another significant way of enriching the teaching of global education is through introducing innovative global education pedagogies. Hakenson (1999) poses important questions about the relationship between global education and pedagogy, that; "Is there a pedagogy of global education? Is it consistent with ways in which schools are changing?" (p. 3). The connection between teaching for global perspectives and school reform is made stronger when examining the pedagogy of global education. This pedagogy is reform oriented and includes cooperative learning, uses interdisciplinary themes, emphasizes critical thinking and problem solving tasks, is experiential, and is community based (Haakenson, 1999). Using an innovative pedagogy of global education may enhance teaching and the accomplishment of the goals of global education.

The following recommendations from the study are suggested for consideration:

(1) In-service training for social studies teachers on global education pedagogies and the use of technology needs special attention.

(2) Teacher Educators need to strengthen their programs towards a global perspective in order to be able "to walk the walk and talk the talk" more.

(3) In-service and pre-service teachers require to be prepared to infuse global perspectives in their daily classroom practices and instruction.

(4) Pre-service and In-service teachers be provided with an opportunity to engage in study abroad programs in order to learn from their counterparts. 


\section{References}

Bruce, M. G., Podemski, R. S., \& Anderson, C. M. (1991). Developing a Global Perspective: Strategies for Teacher Education Programs. Journal of Teacher Education, 42(1), 21-27. http://dx.doi.org/10.1177/002248719104200104

Haakenson, P. (1999). Teacher education reform and global education. International Journal of Social Education, 13(2), 29-47.

Hanvey, R. (1976). An Attainable Global Perspective. New York: The war/peace center.

Holden, C., \& Hicks, D. (2007). Making Global Connections: The Knowledge, Understanding and Motivation of Trainee Teachers. Teaching and Teacher Education, 23, 13-23. http://dx.doi.org/10.1016/j.tate.2006.04.031

Global Education (n.d.). Retrieved July 10, 2013, from http://www.globaleducation.edu.au/global-education/what-is-global-ed.html

LeCompte, M. D., \& Preissle, J. (1993). Ethnography and Qualitative Design in Educational Research. New York: Academic press.

Lincoln, Y., \& Guba, E. (1985). Naturalistic Inquiry. Beverly Hills, CA: Sage.

Mautle, G. (2000). Social studies in Botswana. In M. B. Adeyemi (Ed.), Social Studies in African Education (pp. 157-168). Gaborone: Pyramid.

Merryfield, M. M. (1991). Preparing American Secondary Social Studies Teachers to Teach with a Global Perspective: A Status Report. Journal of Teacher Education, 42(1), 11-20. http://dx.doi.org/10.1177/002248719104200103

Merryfield, M. M. (1993). Reflective Practice in Global Education: Strategies for Teacher Educators. Theory and Practice, 32(1), 27-32. http://dx.doi.org/10.1080/00405849309543569

Merryfield, M. M. (1997). Infusing Global Perspectives into the Social Studies Curriculum. In E. W. Ross (Ed.). The Social Studies Curriculum: Purposes, Problems, and Possibilities. (pp. 183-195). New York: State university press.

Merryfield, M. M. (2000). Why aren't teachers being prepared to teach for diversity, equity, and global interconnectedness? A study of lived experiences in the making of multicultural and global educators. Teaching and Teacher Education, 6, 429-443. http://dx.doi.org/10.1016/S0742-051X(00)00004-4

Merryfield, M. M. (2012). Four strategies for teaching open-mindedness. Social Studies and the Young Learner, 25(2), 18-22. Retrieved August 20, 2013 from http://www.socialstudies.org/publications/ssyl

Merryfield, M. M., \& Tlou, J. (1995). The process of Africanizing the social studies. Social Studies, 86(6), 1-19. http://dx.doi.org/10.1080/00377996.1995.9958406

Merryfield, M. M., \& Wilson, A. (2005). Social Studies and the world: Teaching global perspectives. National Council for the Social Studies, Bulletin 103. Maryland: NCSS. 


\section{Macrothink}

International Research in Education

ISSN 2327-5499

2014, Vol. 2, No. 1

Mhlauli, M. B. (2010). Social studies teachers' perceptions and practices for educating citizens in a democracy in upper classes in primary schools in Botswana. Unpublished $\mathrm{PhD}$ Dissertation, Columbus: Ohio State University. Retrieved April 23, 2013, from http://rave.ohiolink.edu/etdc/view?acc_num=osu1291140441

Mhlauli, M. B. (2011). Understanding the Social studies teachers' experiences: Conceptions of citizenship in Botswana. International Journal of Scientific Research in Education, 4(3\&4), 165-180.

Myers, J. P. (2006). Rethinking the social studies curriculum in the context of globalization: Education for global citizenship in the US. Theory and Research in Social Education, 34(3), 370-394. http://dx.doi.org/10.1080/00933104.2006.10473313

Tucker, J. L., \& Cistone, P. J. (1991). Global perspectives for teachers: An urgent priority. Journal of Teacher Education, 42(1), 3-10. http://dx.doi.org/10.1177/002248719104200102

Willard-Holt, C. (2001). The impact of a short-term international experience for pre-service teachers. Teaching and Teacher Education, 17, 505-517. http://dx.doi.org/10.1016/S0742-051X(01)00009-9

Wilson, A. H. (1993). Conversation partners: Helping students gain a global perspective through cross-cultural experiences. Theory into Practice, 32(1), 21-26. http://dx.doi.org/10.1080/00405849309543568

\section{Copyright Disclaimer}

Copyright reserved by the authors.

This article is an open-access article distributed under the terms and conditions of the Creative Commons Attribution license (http://creativecommons.org/licenses/by/3.0/). 